\title{
"Como o pH afeta a qualidade do solo?": a utilização de uma oficina experimental problematizadora para a análise dos três momentos pedagógicos
}

Willian Hideki Takarada hidetak10@gmail.com 0000-0002-0731-6599 Universidade Federal do Paraná, Curitiba Paraná, Brasil.

Joanez Aparecida Aires joanez.ufpr@gmail.com 0000-0002-2925-0826 Universidade Federal do Paraná, Curitiba, Paraná, Brasil.

\section{RESUMO}

A Química é uma disciplina considerada complexa e desinteressante para grande parte dos estudantes do Ensino Médio. Consideramos que uma forma de torná-la mais interessante e assimilável aos alunos, consiste na utilização da experimentação problematizadora em conjunto com a abordagem de Ciência, Tecnologia e Sociedade (CTS), uma vez que tais abordagens podem tornar o Ensino de Química mais contextualizado e desenvolver a criticidade nos alunos. Este estudo teve como objetivo elaborar e aplicar uma Oficina Experimental Problematizadora, bem como analisar os três momentos pedagógicos e sua influência no desenvolvimento cognitivo e crítico do discente a partir da pergunta "Como o $\mathrm{pH}$ afeta a qualidade do solo?". A oficina foi realizada dentro do conteúdo de ácidos, bases, $\mathrm{pH}$ e indicadores de $\mathrm{pH}$ e contou com a participação de alunos de um curso pré-vestibular. A partir da análise das discussões realizadas antes e após cada etapa, observou-se que a experimentação problematizadora possibilitou o desenvolvimento do conhecimento científico ao mesmo tempo que permitiu uma reflexão crítica da realidade, no que diz respeito a conceitos químicos. Ressalta-se ainda que a Oficina promoveu o primeiro contato de alunos de um curso pré-vestibular solidário com uma atividade experimental, constituindo-se este fato talvez, no seu principal mérito.
\end{abstract}

PALAVRAS-CHAVE: Experimentação problematizadora. Indicador de repolho roxo. CTS. 


\section{INTRODUÇÃO}

No atual cenário das escolas de Ensino Médio no Brasil, a Química é considerada pelos alunos como uma das disciplinas mais complexas e menos interessantes a serem estudadas. Esse senso comum se deve a uma série de fatores, dos quais é possível destacar a apresentação, por parte dos docentes, de um ensino de Química cujos conteúdos são desvinculados das vivências cotidianas do aluno e, portanto, não significativos. Esse fator tem como consequência a não aprendizagem dos discentes e ainda o desinteresse destes na disciplina.

Desse modo, um dos maiores desafios da área de Ensino de Ciências está na abordagem dos conteúdos em sala de aula: no planejamento de como proporcionar a aproximação da Ciência ao cotidiano do aluno, de fazê-los confrontar e aperfeiçoar seus conhecimentos prévios e também a maneira de compreender e analisar criticamente as relações das Ciências e seu dia a dia. Outro desafio consiste em apresentar o conteúdo curricular de forma atrativa aos alunos, de modo a despertar o interesse e o real envolvimento destes com os assuntos propostos, auxiliando no desenvolvimento cognitivo e da criticidade.

Como forma de atrelar os conhecimentos teóricos da Química às ações realizadas ou presentes no dia a dia, a experimentação problematizadora surge como uma ferramenta didática necessária. Vincular aspectos reais e cotidianos aos temas escolares da Química é atribuir significado ao aprendizado do aluno, além de possibilitar o interesse e motivar o engajamento do aluno com a disciplina.

Mais do que isso, somada à experimentação problematizadora, é possível realizar a contextualização do conhecimento construído dentro das discussões de Ciência, Tecnologia, Sociedade (CTS), tendo em vista que o papel primordial da escola é servir de aporte para a formação de alunos que saibam seu papel social conjuntamente com senso crítico em prol da cidadania. A prática escolar relacionada à abordagem CTS permite a discussão dos assuntos que permeiam o vínculo entre conhecimento científico e o desenvolvimento tecnológico e como ambos afetam a sociedade. Desse modo, a associação entre experimentação problematizadora e abordagem de CTS no Ensino de Química possibilita uma educação problematizadora e reflexiva. O conteúdo escolar tem o papel então de promover um ensino crítico, um propósito de transformação, de repensar a maneira de ver o mundo e de como agir nele.

Nesse contexto, o presente trabalho teve como objetivo analisar como cada um dos três momentos pedagógicos, propostos por Delizoicov (2001), contribui para o desenvolvimento do conhecimento científico dos discentes. Para isso, foi realizada uma oficina didática de Química dentro dos conteúdos de ácidos, bases, $\mathrm{pH}$ e indicadores de $\mathrm{pH}$, abrangendo atividades experimentais investigativas e temas de discussões envolvendo a abordagem de CTS. A oficina intitulada "Como o pH afeta a qualidade do solo?" foi elaborada para ter uma duração de quatro horas e contou com duas etapas: i) discussão dialogada e ii) atividade experimental problematizadora, sendo esta última separada em duas partes. A avaliação dos momentos pedagógicos foi realizada por meio das respostas registradas dos alunos antes e após cada etapa da oficina, em que a discussão dialogada foi utilizada para analisar o primeiro momento pedagógico, a primeira parte do experimento para o segundo momento pedagógico e a segunda parte do experimento para o terceiro momento pedagógico. 
Sendo assim, a oficina foi realizada em uma sala de aula para 26 discentes de um curso preparatório para vestibular, na qual se buscou uma maneira de possibilitar aos alunos a compreensão de conteúdos curriculares da Química aliados à prática experimental, ampliar a visão de Ciência e promover a análise crítica de casos cotidianos relacionados às outras Ciências, ao desenvolvimento tecnológico e à sociedade, visando a formação dos alunos enquanto cidadãos.

\subsection{A QUÍMICA NO CONTEXTO DO ENSINO MÉDIO}

A Química apresenta uma característica bastante fascinante ao oferecer explicações sobre diversos fenômenos naturais e funcionamento de maquinários ao nosso redor, mesmo que muitas dessas explicações sejam bastante complexas. Desse modo, no contexto escolar, o aprendizado da Química é imprescindível e os educadores da Química possuem uma responsabilidade e um desafio muito grande ao levar esta disciplina à sala de aula.

Além disso, promover somente o ensino dos conceitos teóricos da Química em sala de aula é improdutivo para a aprendizagem dos alunos e não reflete toda a importância desta disciplina para as atividades do cotidiano e para a sociedade.

No estudo realizado por Cardoso e Colinvaux (2000), é possível verificar que alunos de Ensino Médio demonstram dificuldades na assimilação dos conteúdos de Química e consideram a disciplina como desinteressante ou sem utilidade na vida cotidiana. Sendo assim, há necessidade de um ensino problematizador e contextualizado à realidade do aluno. Segundo Chassot (2010, p. 130), "o conhecimento químico, tal como é usualmente transmitido, desvinculado da realidade do aluno, significa muito pouco para ele".

No entanto, é necessário considerar que o aluno possui ideias de senso comum, que são concepções mal compreendidas, bem como conhecimentos prévios adquiridos em suas vivências pessoais, em relação ao conhecimento científico, que influenciam sua aprendizagem, mesmo que estas apresentem limitações e erros. Segundo Peduzzi (2001), a tentativa de explicação de um fenômeno desenvolve-se no indivíduo antes da idade escolar, o denominado senso comum, e trata-se de concepções estruturais elaboradas que apresentam uma compreensão coerente sob o ponto de vista do indivíduo. Por isso, o senso comum do aluno não deve ser ignorado, mas confrontado.

Considerando os conhecimentos prévios do aluno, para problematizar, o professor deve apresentar um problema que tenha algum significado para o estudante, conscientizando-o de que há necessidade de um conhecimento inédito para a resolução. Ao mesmo tempo, o docente também deve localizar as limitações e contradições dos conhecimentos expressados pelos alunos para que então possam ser determinadas as maneiras de buscar uma resposta (DELIZOICOV, 2001).

Mais do que entender o que acontece a sua volta como estudante, o aluno deve ter capacidade de interferir e mudar o seu entorno enquanto cidadão. Há uma busca dos educadores em capacitar e "formar cidadãs e cidadãos que não só saibam ler melhor o mundo onde estão inseridos, como também, e principalmente, sejam capazes de transformar este mundo para melhor" (CHASSOT, 2010, p. 101). 
Nessa missão de promover um ensino mais crítico, o cotidiano é um elemento essencial para a formação escolar. Entender as relações do cotidiano com a sociedade é ter conhecimento de como agir sobre ele. A partir da discussão de Wartha, Silva e Bejarano (2013), é possível entender que o termo "cotidiano" vem sendo substituído por outro mais abrangente de "contextualização", inclusive em documentos oficiais, que permite diversas interpretações. Sendo assim, antes da discussão do trabalho é necessário identificar o que está sendo tratado.

Neste trabalho, a proposta é praticar o conceito de contextualização a partir de uma experimentação problematizadora, abrangendo os três momentos pedagógicos propostos por Delizoicov (2001) trabalhados conjuntamente à abordagem de Ciência, Tecnologia e Sociedade (CTS). Desse modo, busca-se proporcionar ao aluno um Ensino de Ciências que possibilite um "entendimento mais complexo do que a simples exemplificação do cotidiano ou mera apresentação superficial de contextos sem uma problematização que de fato provoque a busca de entendimento sobre os temas de estudo" (WARTHA; SILVA; BEJARANO, 2013).

\subsection{EXPERIMENTAÇÃO PROBLEMATIZADORA}

É consenso entre os professores que as atividades experimentais intrínsecas aos conteúdos científicos são necessárias para que se propicie o desenvolvimento cognitivo e se desperte no aluno o interesse pelo assunto, sendo uma ferramenta eficiente para a criação de problemas reais que permitam a contextualização (FRANCISCO JR.; FERREIRA; HARTWIG, 2008; GUIMARÃES, 2009). A divergência está na maneira pela qual as experimentações são desenvolvidas.

A experimentação é uma ferramenta muito poderosa no processo de aprendizagem e também muito versátil, de natureza social, técnica e cognitiva, conforme discutido por Giordan (1999). Dentre estas múltiplas funções, as mais discutidas são as experimentações ilustrativa e investigativa (GIORDAN, 1999; FRANCISCO JR.; FERREIRA; HARTWIG, 2008). Na experimentação ilustrativa, o experimento tem como propósito apenas a exemplificação ou demonstração de um conteúdo teórico explicado anteriormente em sala de aula, sem muito debate ou reflexão posterior. A experimentação investigativa, por outro lado, é empregada anteriormente à explicação de conceitos, visando armazenar informações de forma sistematizada que possibilitem posterior discussão, reflexão e explicações, levando o aluno a compreender os conteúdos, mas também a realizar e analisar diferentes formas de pensar sobre o cotidiano e a ciência (GIORDAN, 1999; DELIZOICOV, 2001; FRANCISCO JR.; FERREIRA; HARTWIG, 2008). No contexto deste trabalho, a experimentação investigativa foi tratada como experimentação problematizadora, tendo em vista a utilização dos três momentos pedagógicos de Delizoicov decorrentes da pedagogia problematizadora de Paulo Freire.

Em suas obras sobre saberes necessários à profissão de docente, Freire critica a "educação bancária", onde o aluno é visto como um recipiente vazio a ser preenchido pelo educador que deve depositar o conhecimento. Nas palavras de Freire (2013, p. 81), "na visão 'bancária' de educação, o 'saber' é uma doação dos que se julgam sábios aos que julgam nada saber". Nessa perspectiva, aqueles que 
possuem melhor memorização e que aceitam melhor os conteúdos como verdades são melhores educandos.

Nesse contexto caótico, é dever do educador estar ciente de "saber que ensinar não é transferir conhecimento, mas criar possibilidades para a sua própria produção ou a sua construção" (FREIRE, 2011, p. 33). Para tal desafio, Freire discute diversos recursos que podem ser utilizados para uma educação mais problematizadora ou libertadora.

Como maneira de transmitir as concepções de Paulo Freire para o contexto da sala de aula, o físico e educador Delizoicov $(1983,2001)$ estruturou um modelo de três momentos pedagógicos para um ensino problematizador, que podem também ser aplicados por meio de uma atividade experimental: a) problematização inicial; b) organização do conhecimento; c) aplicação do conhecimento.

No primeiro momento, a chamada problematização inicial ocorre quando há apresentação de situações corriqueiras à realidade dos alunos para que se inicie a discussão. Ao mesmo tempo que os alunos expõem suas ideias e explicitam seu conhecimento prévio sobre o assunto, o professor tem o dever de mediar tal discussão, no sentido de problematizar o conhecimento exposto pelos alunos através de questionamentos. $O$ intuito da problematização é gerar dúvidas sobre o que está sendo discutido, evidenciar explicações contraditórias e perceber limitações conceituais do conhecimento, fazendo com que o aluno compreenda e sinta a necessidade da aquisição de outro conhecimento para poder explicar o assunto em debate.

No segundo momento, a organização do conhecimento é realizada por meio da apresentação sistematizada dos conhecimentos necessários para entender o assunto discutido anteriormente no primeiro momento. Os mais variados recursos podem ser utilizados para a compreensão científica das situações que estão sendo problematizadas: desde os tradicionais problemas de lápis e papel, reportagens e textos, até os atuais jogos didáticos, histórias em quadrinhos e vídeos explicativos.

No terceiro momento, a aplicação do conhecimento, o aluno é levado a analisar e interpretar a situação inicial de forma sistematizada, utilizando-se do conhecimento que foi agregado. Mais do que compreender a situação inicial, o discente também deve ser capaz de identificar, interpretar e analisar outras situações nas quais o mesmo conhecimento pode ser abordado. Isso ocorre por intermédio do professor, cujo dever é desenvolver uma atividade como forma de generalizar a conceituação.

Desse modo, no contexto de experimentação embasada pelo modelo dos três momentos pedagógicos, "a atividade experimental problematizadora deve propiciar aos estudantes a possibilidade de realizar, registrar, discutir com os colegas, refletir, levantar hipóteses, avaliar as hipóteses e explicações, discutir com o professor todas as etapas do experimento" (FRANCISCO JR; FERREIRA; HARTWIG, 2008).

Ainda com o objetivo de propiciar um ensino crítico contextualizado à realidade do aluno, a abordagem CTS pode ser incluída na realização do experimento. Segundo Chassot (2010), a cidadania crítica é um tema atual e mais próximo do que se imagina, sendo a dimensão ambiental da educação 
imprescindível para fazer um ensino mais político, ou seja, de construção da cidadania.

\subsection{CIÊNCIA, TECNOLOGIA E SOCIEDADE (CTS)}

As questões ambientais têm sido destaque na mídia nacional e internacional devido ao grande desenvolvimento industrial, que trouxe consigo a emissão de inúmeros poluentes ao meio ambiente e degradação de reservas ambientais. Nesse cenário preocupante, iniciou-se o interesse por processos industriais menos agressivos à natureza, de modo a não comprometer o futuro das próximas gerações e, ao mesmo tempo, atender as demandas da população.

Santos e Schnetzler conseguem descrever a dimensão do problema no âmbito educacional:

A presença da química no dia-a-dia das pessoas é mais do que suficiente para justificar a necessidade de o cidadão ser informado sobre química. Todavia, o ensino atual de nossas escolas está muito distante do que o cidadão necessita conhecer para exercer a sua cidadania (SANTOS; SCHNETZLER, 2003, p. 13).

Segundo Chassot (2010), há um desafio muito grande na docência em envolver os estudantes em discussões de problemas que são mais próximos. Nesse ponto de vista, não se anula a importância com que se deve olhar para os grandes problemas ambientais, mas estes não são de uma solução imediata ou que dependa somente deles. Nessa perspectiva, é lembrar que problemas ambientais também são encontrados no lixão do bairro, nos rios poluídos da cidade ou na falta de saneamento básico de uma região. São estes problemas mais próximos que devem ter uma primeira atenção para então haver uma posterior preocupação com os problemas maiores.

Nas palavras de Chassot (2010), problemas mais próximos da realidade "são suficientemente relevantes para transformar nossas alunas e nossos alunos em mulheres e homens críticos, que serão responsáveis pela construção de uma sociedade com menos desigualdades". Isso porque os alunos adquirem a capacidade de analisar e interpretar um problema, pensar em soluções e elaborar uma proposta para que possa agir de fato na solução desse problema.

Desse modo, Chassot também é capaz de exemplificar toda a ideia de maneira simples:

[...] aquela aluna que souber orientar sua mãe para que esta procure usar proteção para as mãos e para os olhos quando trabalha com produtos domosanitários agressivos é mais ambientalista do que se estivesse discutindo os riscos dos derivados de fluorcarbonetos para a camada de ozônio (CHASSOT, 2010, p. 140).

Nessa perspectiva, é possível perceber a necessidade de um modelo de ensino entrelaçado aos temas e discussões de CTS. Santos e Schnetzler também descrevem a diferença encontrada nos currículos de ensino clássico e nos currículos em que a abordagem CTS está presente: 
as implicações sociais do conhecimento científico. Por outro lado, o ensino clássico é caracterizado pela concepção de ciência universal, que possui valor por si mesma e não pelas suas aplicações sociais (SANTOS; SCHNETZLER, 2003, p. 64).

Para os currículos de ensino médio, segundo Santos (2008), o primeiro relato para a contextualização explicitando a discussão de temas englobando ciências e tecnologia foi feito no documento dos Parâmetros Curriculares Nacionais (PCN), no ano 2000.

O texto dos PCN, atualizado ao longo dos anos, hoje deixa claro que deve haver uma discussão entre Ciência e Tecnologia com suas consequências para a Sociedade e o Meio Ambiente, além de enfatizar a importância da interdisciplinaridade e contextualização dos conteúdos do Ensino Médio.

Apesar das recomendações, as Ciências Naturais, das quais faz parte a Química, tem sido muitas vezes ministrada nos colégios de forma mecânica e totalmente desconectada do cotidiano. Como não há essa ligação entre o conhecimento e o dia a dia, os alunos "entendem que o estudo de ciências se resume a memorização de nomes complexos, classificação de fenômenos e resolução de problemas por meio de algoritmos" (SANTOS, 2008).

Sendo assim, deve haver uma abordagem crítica da CTS em sala de aula, fazendo com que o aluno amplie sua visão sobre Ciências, sendo capaz de discutir criticamente a respeito de questões políticas, sociais, econômicas, culturais, éticas e ambientais. Embora haja construção de valores nessas temáticas, de nada vale essa discussão se desvinculada do conhecimento social e científico.

\section{METODOLOGIA}

O objeto de estudo foi constituído a partir da elaboração, aplicação e análise de uma Oficina Experimental Problematizadora, abrangendo os três momentos pedagógicos descritos por Delizoicov e contextualizados à abordagem de CTS. Desse modo, o presente estudo contou com a análise de respostas de discussões prévias e posteriores, apresentadas pelos participantes no contexto dessa oficina, planejada para a disciplina de Química. Para isso, a atividade foi realizada em um curso pré-vestibular solidário na região de Curitiba e contou com 26 alunos de faixa etária entre 17 e 22 anos, conforme organizado no gráfico da Figura 1.0 projeto já atendeu mais de 6000 alunos de baixa renda do município e região metropolitana com o sonho de ingressar em uma instituição de Ensino Superior. A oficina intitulada "Como o pH afeta a qualidade do solo?" teve duração de 4 horas e foi realizada em um feriado, dia letivo especial para os alunos do curso. Deve-se ressaltar ainda que este foi o primeiro contato dos alunos com uma atividade experimental. 
Figura 1 - Gráfico da faixa etária dos alunos participantes

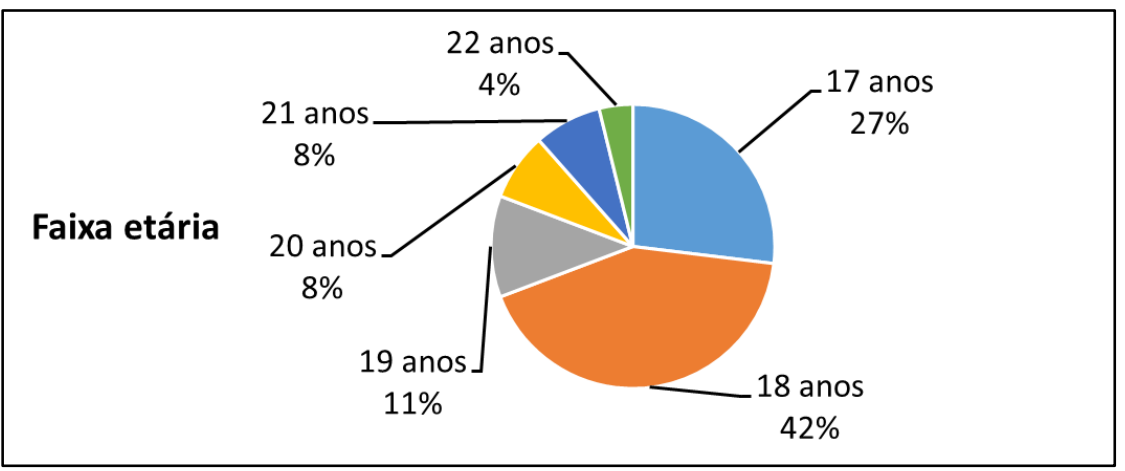

Fonte: Autores com base nos dados coletados (2018).

Os conteúdos escolhidos para o trabalho foram ácidos, bases, $\mathrm{pH}$ e indicadores de $\mathrm{pH}$. A oficina foi preparada em duas etapas: i) discussão dialogada e ii) atividade experimental problematizadora, sendo a parte experimental separada em duas partes. A avaliação dos momentos pedagógicos foi realizada por meio das respostas registradas dos alunos antes e após cada etapa da oficina, na qual a discussão dialogada foi utilizada para analisar o primeiro momento pedagógico, a primeira parte do experimento para o segundo momento pedagógico e a segunda parte do experimento para o terceiro momento pedagógico.

Para a constituição dos dados para análise da oficina e dos momentos pedagógicos, foram elaboradas perguntas a serem respondidas pelos alunos, de maneira escrita e/ou oral, individual e/ou coletiva, antes e depois de cada etapa do experimento para avaliar o desenvolvimento do conhecimento científico no decorrer de cada momento pedagógico, conforme descrito nos Quadros 1, 2 e 3 a seguir:

Quadro 1 - Questões para análise do primeiro momento pedagógico

Questões discutidas antes e após discussão dialogada

1. O que são substâncias ácidas e básicas?

2. Quais produtos do cotidiano são ácidos? Cite pelo menos 3.

3. Quais produtos do cotidiano são básicos? Cite pelo menos 3 .

4. É possível identificar se uma substância é ácida ou básica? Como?

Fonte: Autor (2018).

Quadro 2-Questões para análise do segundo momento pedagógico

Questões antes da Parte I do Experimento foi realizado na aula?

\section{Questões após a Parte I do Experimento}

1. Agrupe as amostras conforme a cor da solução final. Você consegue identificar substâncias ácidas, básicas ou neutras de acordo com a cor? Levando em conta o indicador de repolho roxo, qual cor corresponde a cada uma delas? 
2. O que é um indicador universal de $\mathrm{pH}$ ?

a

2. Quais outras substâncias do seu dia a dia podem ser adicionadas ao grupo dos ácidos? E quais podem ser adicionados ao grupo das bases?

3. Qual a cor final dos copos contendo água? Qual pH associado a estas cores? Você esperava que a água da torneira demonstrasse essa cor? Por quê?

4. O que é um indicador de $\mathrm{pH}$ universal? Que indicadores de $\mathrm{pH}$ universal você conhece?

Fonte: Autor (2018).

Quadro 3-Questões pré e pós-terceiro momento pedagógico

Questões antes da Parte II do experimento

1. É importante determinar o pH dos solos? Por quê?

2. Você sabe o que é calagem? Para que serve? O $\mathrm{pH}$ do solo aumenta ou diminui depois da calagem?

3. $\mathrm{O}$ pH dos solos interfere na produção de alimentos? Como?
Questões após a Parte II do experimento

1. É importante determinar o $\mathrm{pH}$ dos solos? Por quê?

2. Você sabe o que é calagem? Para que serve? $\mathrm{O} \mathrm{pH}$ do solo aumenta ou diminui depois da calagem?

3. $\mathrm{O}$ pH dos solos interfere na produção de alimentos? Como?

4. Além de produtos, onde mais podemos encontrar ácidos e bases em nosso cotidiano?

Fonte: Autor (2018).

\subsection{PRIMEIRO MOMENTO PEDAGÓGICO: PROBLEMATIZAÇÃO INICIAL}

No primeiro momento pedagógico foi realizado um diálogo mediado através de questionamentos direcionados pelo professor com o objetivo de fazer um levantamento dos conhecimentos prévios apresentados pelos alunos, assim como abrir possibilidade para despertá-lo de dúvidas, interesse a respeito do tema e discussões sobre o assunto com os colegas.

Como parte do diálogo, os alunos foram questionados quanto seus conhecimentos prévios e opiniões sobre as seguintes perguntas:

- O que são substâncias ácidas e básicas? Qual a diferença entre elas?

- É possível identificar se um produto é ácido ou básico? Como?

- É importante identificar se um produto é ácido ou básico? Por quê?

- Quais produtos você utiliza e que podem ser considerados ácidos ou básicos?

- Qual a importância em determinar acidez ou basicidade da água? E do solo?

- Você já ouviu falar sobre pH? E indicadores de pH? Para que servem? 
As perguntas propostas e a discussão realizada de forma dialogada buscaram promover uma reflexão nos alunos a respeito da relação entre os conteúdos de Química com o cotidiano. Ao mesmo tempo, o primeiro momento pedagógico serviu como introdução à oficina didática.

O recurso utilizado para atender às próximas etapas de apresentação e aplicação sistematizada do conhecimento abrangeu as etapas experimentais da oficina didática de Química envolvendo $\mathrm{pH}$ e indicadores ácido-base. Para a realização da oficina, foi elaborado um roteiro intitulado: "Como o pH afeta a qualidade do solo?", presente no Anexo 1.0 roteiro experimental é dividido em duas partes, onde a primeira parte é intitulada de "Construção da escala universal

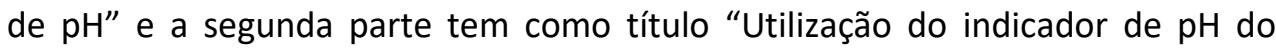
repolho roxo na análise dos solos".

\subsection{SEGUNDO MOMENTO PEDAGÓGICO: ORGANIZAÇÃO DO CONHECIMENTO}

O segundo momento pedagógico foi trabalhado por meio da realização, observação e discussão da primeira parte do experimento: a construção da escala de $\mathrm{pH}$ utilizando o indicador de repolho roxo.

Houve uma determinação prévia dos critérios de coleta de dados do experimento. Durante a realização do experimento, cada aluno registrou os dados obtidos na forma da Tabela 01 do Anexo 2. A coleta dos dados foi explicada previamente com o intuito de não haver erros ou confusões na hora do registro, tendo em mente que a tabela foi imprescindível para responder o Questionário 01 e para discussões posteriores.

O propósito dessa etapa do experimento foi gerar mais dúvidas a respeito do porquê da mudança de cor em cada amostra e quais as propriedades associadas a elas. As respostas ao questionário e a construção da escala de $\mathrm{pH}$ com o indicador do repolho roxo serviram como forma de organizar o conhecimento de forma sistematizada.

\subsection{TERCEIRO MOMENTO PEDAGÓGICO: APLICAÇÃO DO CONHECIMENTO}

O terceiro momento pedagógico foi englobado pela segunda parte do experimento: a análise de $\mathrm{pH}$ dos solos. Seguindo o roteiro, foram analisados três tipos de solo: solo com elevada carga de matéria orgânica, solo tratado com calcário e solo encontrado em local próximo ao local do experimento.

O professor também explicou previamente como deveria ser feita a coleta de dados da análise dos solos, conforme a Tabela 02, presente no Anexo 3. Nessa etapa do experimento, esperava-se que o aluno pudesse facilmente determinar o $\mathrm{pH}$ do solo por meio do indicador de repolho roxo, mas que ao mesmo tempo também conseguisse formular hipóteses para a cor encontrada para cada solo.

Após a realização da segunda etapa do experimento, constituição dos dados, reflexão e levantamento de hipóteses, houve uma discussão para possíveis interpretações sobre o experimento dentro do conhecimento científico. Como forma de evidenciar melhor a abordagem CTS à oficina didática, as perguntas norteadoras da discussão foram: 
- Tendo em vista que o Brasil é um país de clima predominante tropical, você consegue explicar o fato da maioria dos solos brasileiros serem de caráter ácido? O que causa a acidez?

- O que é calagem? Por que é necessário realizar a correção do pH do solo em cultivos agrícolas? A correção é realizada para aumentar ou diminuir o $\mathrm{pH}$ do solo?

- Por que as áreas desmatadas necessitam de correção de pH do solo para o cultivo agrícola se no local já existiam grande número de árvores na região?

- Você consegue imaginar de que forma o pH do solo pode afetar a indústria agrícola e o consumo de alimentos?

A discussão destas últimas perguntas teve o intuito de levar o aluno a entender as relações entre o conhecimento científico e o aperfeiçoamento de técnicas científicas com a sociedade e as aplicações ambientais. Além disso, possibilitou-se ao aluno a compreensão do conteúdo de indicadores de $\mathrm{pH}$ dentro de contextos significativos e que extrapolam o conhecimento para outras áreas científicas.

Como forma de analisar os temas tratados na Oficina Experimental Problematizadora e a metodologia de nossa pesquisa, cada um dos três momentos pedagógicos foi analisado separadamente para que fosse viável verificar o papel de cada um no processo de desenvolvimento do conhecimento científico. As respostas aos questionários foram categorizadas como RS (respostas satisfatórias), RPS (respostas pouco satisfatórias) e RI (respostas insatisfatórias) em relação ao conhecimento científico, conforme descrito nos critérios do Anexo 4.

\section{RESULTADOS E DISCUSSÕES}

\subsection{ANÁLISE DO PRIMEIRO MOMENTO PEDAGÓGICO}

O primeiro momento pedagógico foi realizado e analisado por meio da discussão com os alunos a respeito de produtos ácidos e básicos encontrados no cotidiano. Anteriormente à discussão, os alunos responderam às perguntas prévias ao primeiro momento pedagógico.

$\mathrm{Na}$ análise das respostas à questão 1 (Figura 2) anteriores ao primeiro momento, foi possível constatar a dificuldade dos alunos em conceituar o que são substâncias ácidas e básicas, predominando RI. 
Figura 2 - Questão 01 - Primeiro Momento Pedagógico

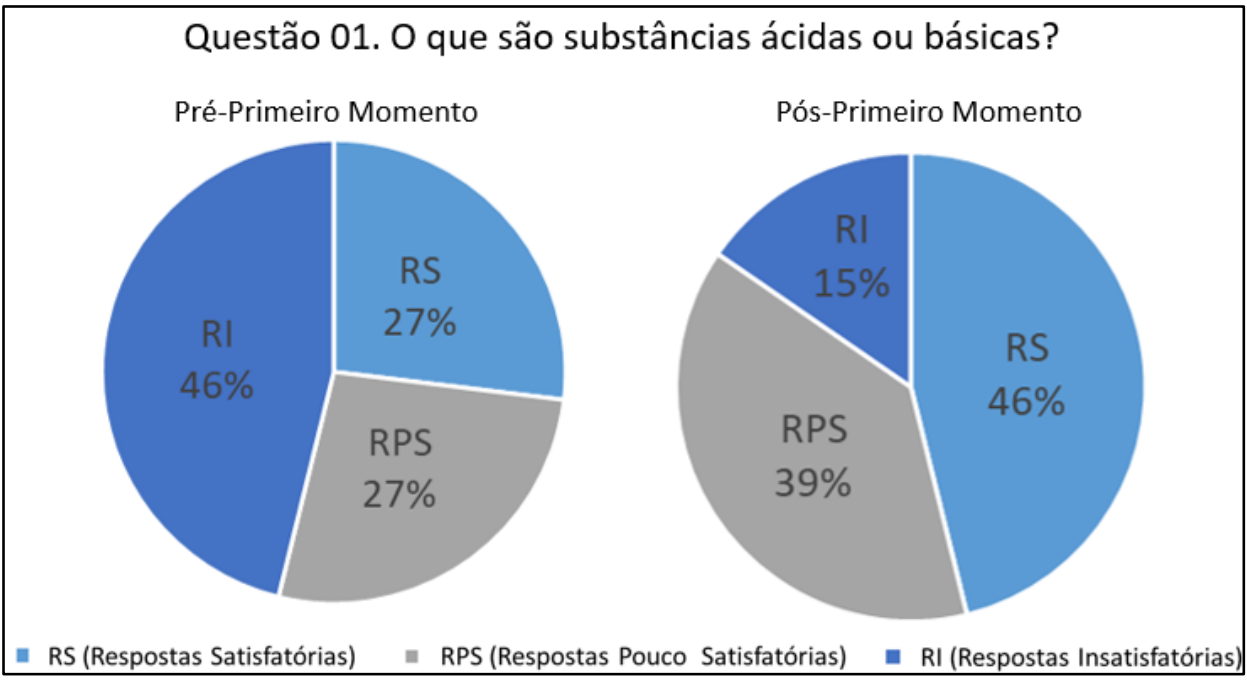

Fonte: Autores (2018).

Pode-se levantar hipóteses de que talvez os alunos não tenham sido apresentados ao tema de maneira proveitosa ou significativa. Daqueles que apresentaram RPS, confundem ou invertem características de ácidos e características de bases:

RPS: "Substâncias ácidas são as que possuem pH alto, geralmente corrosivas. Substâncias básicas são as que possuem pH baixo".

RI: "São substâncias com pH alterado, que dá o caráter a cada uma".

Por meio dos gráficos da Figura 3 que apresentam as respostas às questões 02 e 03, é possível perceber também que os alunos são mais habituados a reconhecer ácidos no cotidiano ( $46 \%$ de RS), sendo capazes de citar vários produtos com composição ácida, mas quando se trata de bases, muitos não conseguem citar ao menos um produto de caráter básico ( $54 \% \mathrm{RI})$. 
Figura 3 - Questões 02 e 03 - Primeiro Momento Pedagógico

Questão 02. Quais produtos do cotidiano são ácidos? Cite 3.

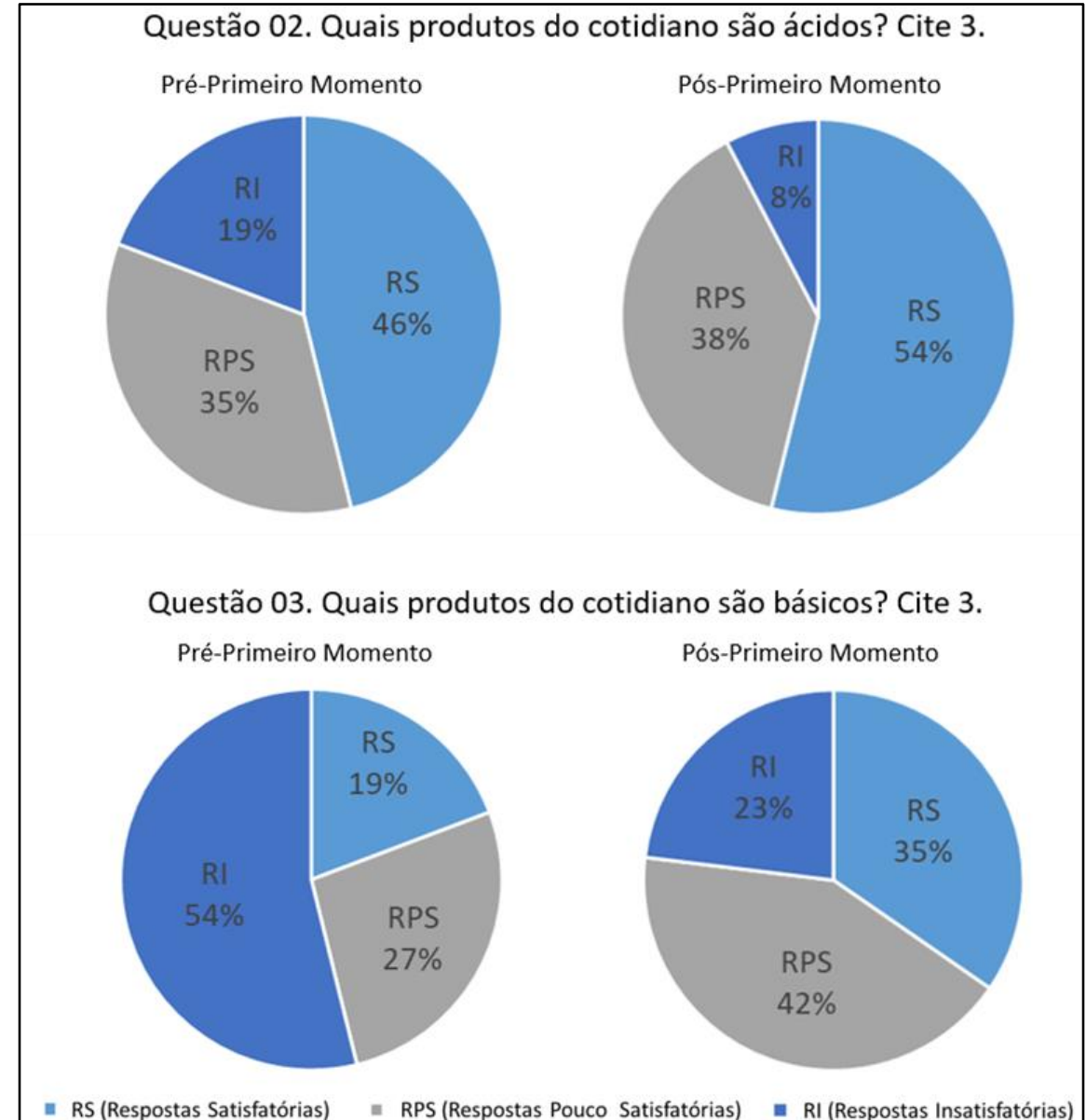

Fonte: Autores (2018).

Na questão 04, conforme a Figura 4, é possível perceber nas respostas anteriores ao primeiro momento que ao serem questionados sobre como determinar a acidez ou basicidade de um composto, a maioria dos discentes consegue citar alguma maneira de realizar a ação (38\% RS), mas é também grande a quantidade de alunos que supõe um experimento químico sem dizer qual (RPS $31 \%)$ ou que dizem não saber (31\% RI):

RS: "Sim, através de indicadores que medem o pH ou lendo o rótulo do produto".

RPS: "Sim, com produtos e experimentos que mudam de cor".

RI: "Sim, é possível, mas precisa de um modo certo, não sei explicar, desculpe". 
Figura 4 - Questão 04 - Primeiro Momento Pedagógico

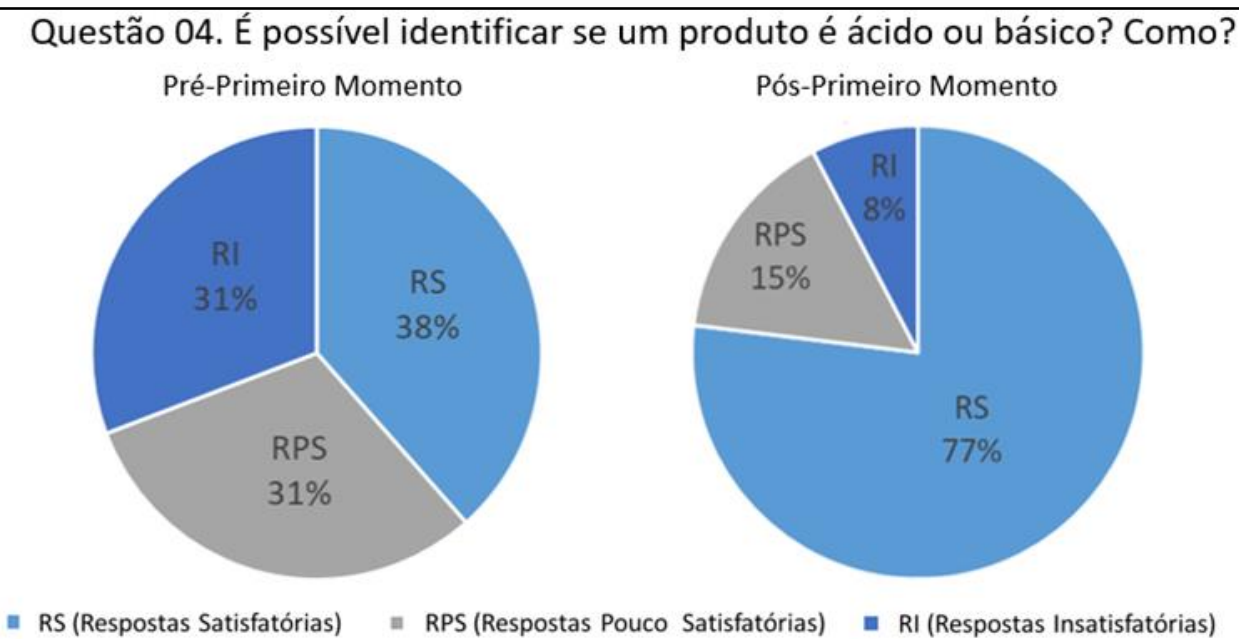

Fonte: Autores (2018).

Após o questionário, foi iniciada então a discussão sobre o assunto. No início, pôde-se perceber a timidez dos alunos e o medo de dar respostas erradas, mas depois das primeiras respostas, muitos alunos participaram da discussão.

No decorrer das falas dos alunos, foi possível observar que surgiram muitas dúvidas em relação ao conceito de ácido-base e quanto a alguns produtos específicos, como por exemplo: se o pH é baixo, o produto é ácido ou básico? A água sanitária é ácida ou básica? Ao mesmo tempo, com base na resposta dos colegas, a discussão também possibilitou que os alunos pudessem relembrar conteúdos que tinham esquecido: alguns deles não lembravam que indicadores de $\mathrm{pH}$ poderiam ser utilizados para determinar acidez ou basicidade, assim como também lembraram que soda cáustica e antiácido estomacal eram substâncias básicas pois neutralizavam acidez. Após o término da discussão que serviu para o levantamento dos conhecimentos prévios dos alunos, assim como forma de relembrar conceitos e produtos e para gerar novas dúvidas, foi reaplicado o mesmo questionário.

Com base nas respostas dos alunos e analisando todos os gráficos de respostas, foi possível verificar diminuição da quantidade de RI nas quatro questões do questionário. Sendo assim, fica claro o importante papel do primeiro momento pedagógico na experimentação problematizadora. Não somente como forma de levantar conhecimentos prévios e gerar novos questionamentos, mas também como espaço para que os próprios alunos possam compartilhar, relembrar e relacionar os conhecimentos que já possuem.

\subsection{ANÁLISE DO SEGUNDO MOMENTO PEDAGÓGICO}

O segundo momento pedagógico foi analisado por uma discussão prévia que abrangia assuntos referentes às questões prévias ao segundo momento. Além disso, foi realizada a primeira parte do experimento que se tratava da construção da escala de $\mathrm{pH}$ universal e foi aplicado um questionário posterior ao segundo momento para avaliar as respostas. 
Na discussão prévia, todos os alunos falaram que nunca tiveram uma oportunidade de participar de um experimento no laboratório, sendo que para alguns, o professor levava para sala uma vez ou outra algum experimento para exemplificar a teoria dada. Ao discutirmos sobre indicadores universais de $\mathrm{pH}$, todos também declararam que não sabiam o porquê do termo "universal", conhecendo somente fenolftaleína e papel tornassol, usualmente utilizados em questões de vestibular. Também sobre o experimento que iria ser realizado, todos os discentes já tinham ouvido falar do extrato de repolho roxo como indicador de $\mathrm{pH}$, mas não sabiam quais cores eram associadas à escala de $\mathrm{pH}$.

O experimento foi realizado com os 26 alunos presentes divididos em 10 bancadas improvisadas no curso pré-vestibular. Na análise das respostas dadas, foi possível notar o grande número de RS dadas pelos alunos. Mais do que isso, ao trabalharem em bancadas, os alunos tiveram espaço para criar suas próprias hipóteses, discutir com os colegas próximos o que fazia ou não sentido associando as cores ao $\mathrm{pH}$ e produtos, além de realizar o preparo de todas as suas amostras, como em um laboratório.

Nas respostas à questão 01 posteriores ao segundo momento (Figura 5), muitos deles associaram corretamente as cores aos produtos e seus respectivos $\mathrm{pH}$, ocorrendo alguns desvios e dúvidas devido à água sanitária. A amostra contendo água sanitária inicialmente adquiriu coloração amarelada, mas depois a solução descorava e ficava transparente. Esse fato foi deixado para ser discutido após as respostas ao questionário pós-segundo momento.

Figura 5 - Questão 01 - Segundo Momento Pedagógico

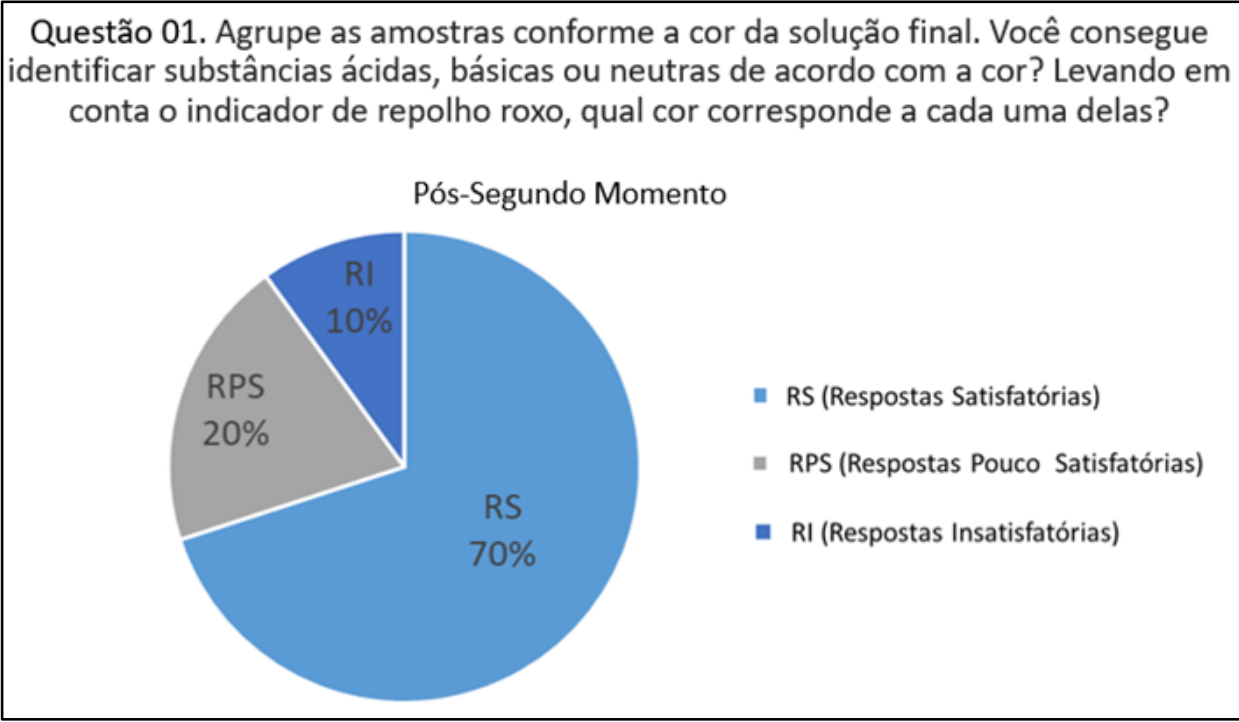

Fonte: Autores (2018).

RS: "Sim, as rosas e avermelhadas são ácidas; as roxas são neutras; os pouco básicos ficaram azuis e esverdeados e as muito básicas ficaram amarelas e transparentes".

RPS: "Sim, rosa-vermelho-roxo são ácidos, azul é neutro e verde-amarelo são básicos"

RI: "Sim, tanto as substâncias mais básicas quanto ácidas são mais claras e quanto mais próxima a substância do neutro ( $\mathrm{pH} 7)$, mais concentrada a sua cor". 
Para as respostas à questão $02,80 \%$ das bancadas foi capaz então de associar produtos cotidianos que pudessem ser acrescentados à lista de produtos ácidos e à lista de produtos básicos, conforme mostra a Figura 6 . Não houve RI, e foram consideradas RPS aquelas que não distinguiam qual produto era ácido e qual era básico.

RS: "Substâncias ácidas: ácido clorídrico, urina, frutas cítricas. Bases: cal, amaciante"

RPS: "Sabonete, antitranspirante e ácido do estômago"

Figura 1 - Questão 02 - Segundo Momento Pedagógico

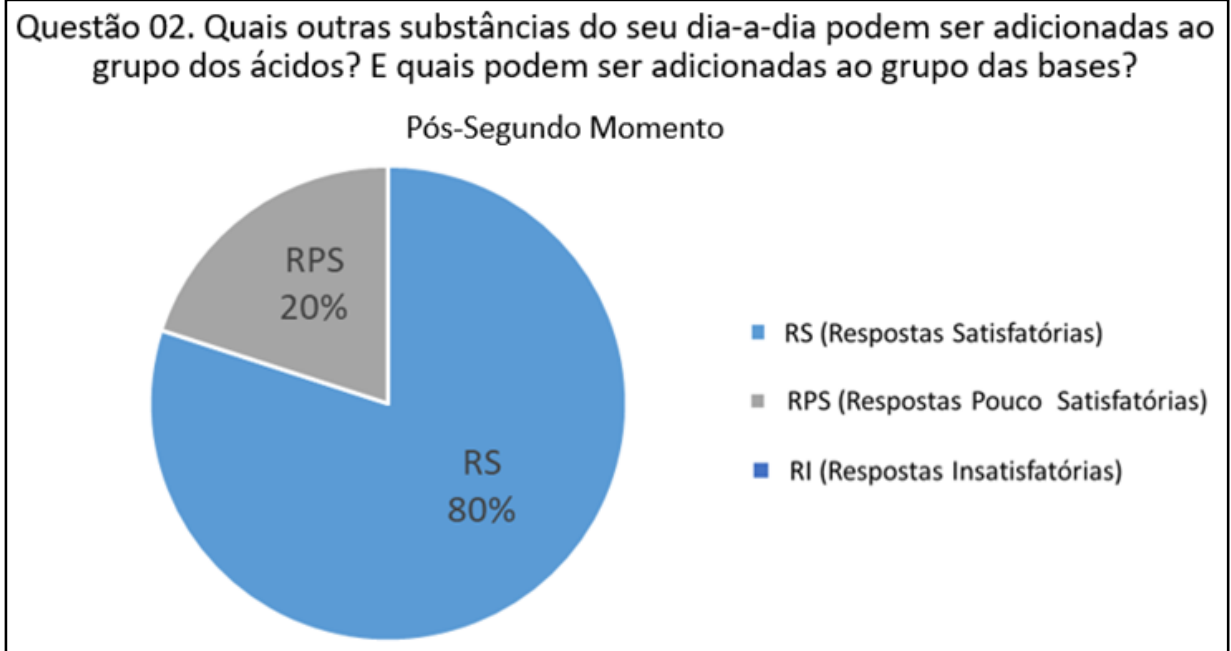

Fonte: Autores (2018).

As respostas à questão 03 (Figura 7) poderiam divergir devido à quantidade de cloro na água. Sendo assim, foram considerados RS as que indicavam o caráter e tentavam explicar o porquê dessa relação.

Figura 7 - Questão 03 - Segundo Momento Pedagógico

Questão 03. Qual a cor final dos copos contendo água? Qual pH está associado a estas cores? Você esperava que a água da torneira demonstrasse essa cor? Por quê? Pós-Segundo Momento

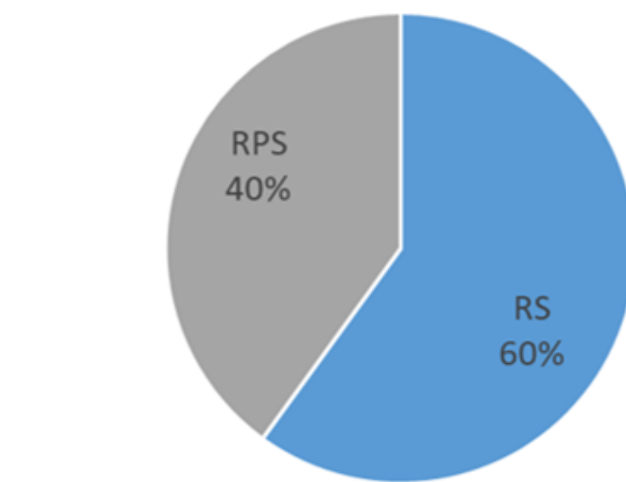

n RS (Respostas Satisfatórias)

n RPS (Respostas Pouco Satisfatórias)

- RI (Respostas Insatisfatórias)

Fonte: Autores (2018). 
RS: “Não esperávamos a cor roxa da água da torneira, pois diferente da água destilada, ela contém sais e impureza, então esperávamos uma cor diferente de roxo".

RS: "Os copos contendo água ficaram roxos, indicando $\mathrm{pH}$ neutro. Não imaginávamos, esperávamos que a água da torneira fosse básica, pela adição de fluoretos e cloretos".

RS: "Sim, porque a água é neutra, logo ela assume a cor roxa".

RPS: “Água destilada e de torneira - roxo. Água sanitária - amarelo".

Nas respostas à questão 04 (Figura 8), foi possível analisar que a maioria dos alunos conseguiu compreender por si só o que é um indicador de $\mathrm{pH}$ universal.

Figura 8 - Questão 04 - Segundo Momento Pedagógico

\section{Questão 04. O que é um indicador de pH universal?} Que indicadores de $\mathrm{pH}$ universal você conhece?

Pós-Segundo Momento

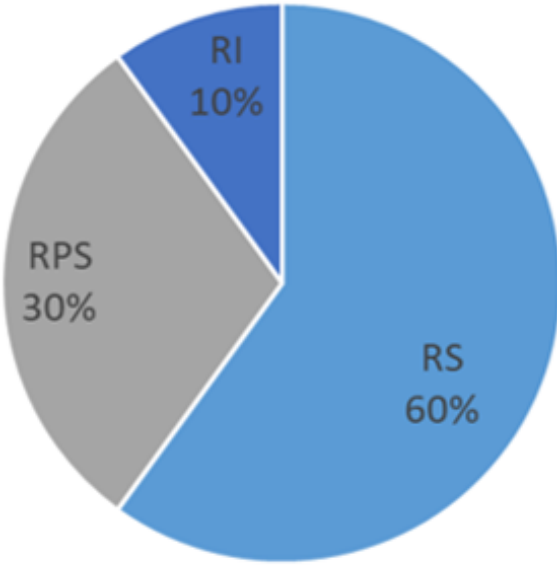

- RS (Respostas Satisfatórias)

n RPS (Respostas Pouco Satisfatórias)

= RI (Respostas Insatisfatórias)

Fonte: Autores (2018).

RS: "É um indicador que aponta qualquer nível de pH. Conhecemos o repolho roxo".

RPS: "É o que indica o ácido-base de qualquer substância. Exemplo: repolho roxo e fenolftaleína".

RI: "Não sabemos o que é um indicador universal de $\mathrm{pH}^{\text {". }}$

Após as respostas ao questionário, foi realizada outra discussão para as dúvidas.

Durante a discussão, entrou em pauta a descoloração da amostra de água sanitária. A água sanitária é um agente oxidante moderado, que acabou oxidando a estrutura da antocianina presente no indicador à base de repolho roxo.

Do mesmo modo, o pH da água da torneira também foi discutido e um grupo levantou a hipótese de que de maneira nenhuma o $\mathrm{pH}$ poderia ser neutro, pois disseram que no colégio teriam explicado que o cloro residual nas águas levaria à formação de hipoclorito. Outro grupo respondeu que nem sempre se observa a 
água branca devido à presença de cloro e sendo assim a concentração e o pH mudam.

Quanto ao termo "universal" empregado no extrato de repolho roxo, uma aluna de uma das bancadas levantou a hipótese de que é devido às diversas cores que são encontradas, conforme as escalas construídas, sendo que os usualmente ensinados (fenolftaleína, papel tornassol) possuem apenas duas cores para indicar ácido-base. Houve então uma surpresa quanto a esse fato, pois muitos não tinham percebido a quantidade e cores de cada indicador de $\mathrm{pH}$.

\subsection{ANÁLISE DO TERCEIRO MOMENTO PEDAGÓGICO}

O terceiro momento pedagógico foi analisado por meio das respostas às questões prévias ao terceiro momento, pela segunda parte do experimento que se tratava da análise de $\mathrm{pH}$ dos solos, e por uma discussão posterior. Os alunos ainda estavam organizados em suas bancadas.

Nas respostas dadas à questão 01 anterior ao terceiro momento (Figura 9), é possível perceber por meio do grande número de RPS (46\%) e RI (15\%), que os alunos sentem a importância de analisar $\mathrm{pH}$ de solos, mas não explicam o porquê.

Figura 9 - Questão 01 - Terceiro Momento Pedagógico

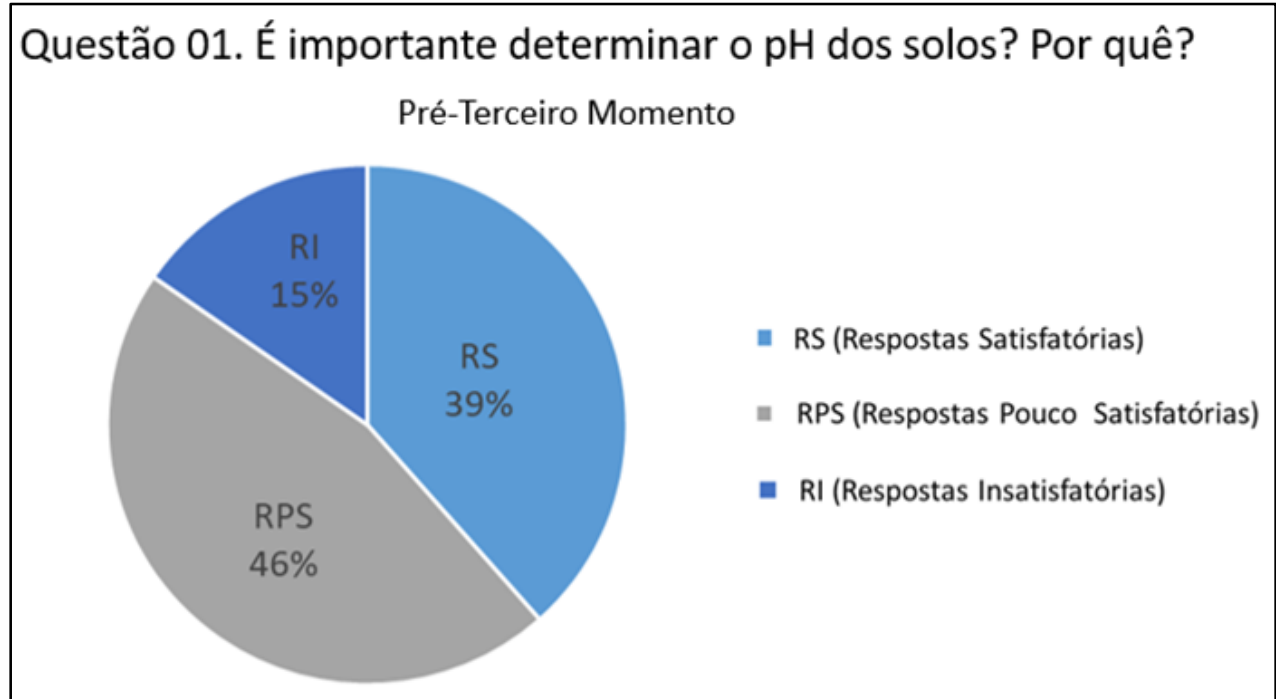

Fonte: Autores (2018).

RPS: "Para manter a saúde dos solos e preservá-los".

RI: “Sim, principalmente em atividades com o solo".

Nas respostas à questão 02 (Figura 10), muitos não conhecem o processo de calagem (65\% RI), importante para a correção do solo para a agricultura. Outros o conhecem, mas ainda fazem confusão com a escala de $\mathrm{pH}$ :

RPS: "Mais ou menos. Achamos que é um processo no qual o cal equilibra o $\mathrm{pH}$ do solo. Se estiver muito ácido, ele diminui o $\mathrm{pH}^{\prime \prime}$.

RI: "Quando trocam as áreas de plantio, intercalando-se entre as áreas o plantio". 
Figura 10 - Questão 02 - Terceiro Momento Pedagógico

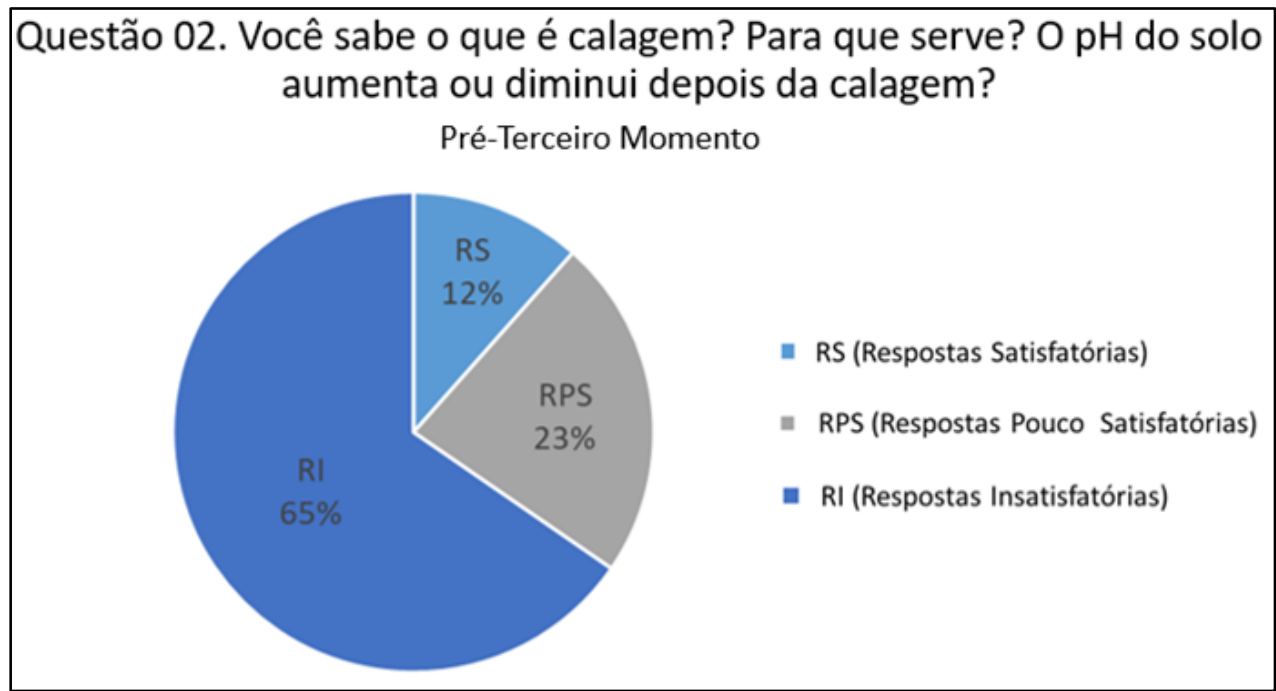

Fonte: Autores (2018).

$\mathrm{Na}$ questão a respeito sobre o impacto do $\mathrm{pH}$ dos solos na agricultura (Figura 11), alguns conseguem associar o $\mathrm{pH}$ do solo à produção ou ecossistemas (39\% RS), outros apresentam RPS (35\%) e RI (31\%):

Figura 11 - Questão 03 - Terceiro Momento Pedagógico

Questão $03 . \mathrm{O} \mathrm{pH}$ dos solos interfere na produção de alimentos? Como? Pré-Terceiro Momento

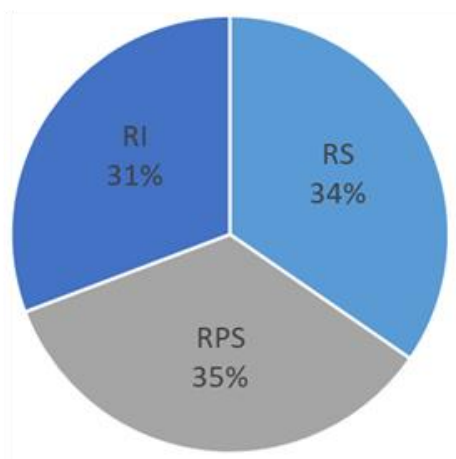

- RS (Respostas Satisfatórias)

In RPS (Respostas Pouco Satisfatórias)

- RI (Respostas Insatisfatórias)

Fonte: Autores (2018).

RPS: "Sim, pois se estiver mais ácido, o alimento não cresce como deveria crescer".

RI: "Sim, dependendo do $\mathrm{pH}$, pode trazer risco à saúde daqueles que consomem ou até cultivam o alimento".

Após o questionário, foram realizados os testes do solo, nos quais foram testados: solo das margens de um rio (solo ácido) e o solo que passou pelo processo de calagem (solo básico). Além disso, foi testada uma amostra de solo do zoológico de Curitiba (apresentou solo neutro), local onde os alunos tiveram uma aula temática antes da Oficina de Química. 
Em seguida, como forma de terminar o experimento, foi aberto mais um espaço para a discussão do terceiro momento pedagógico. Os alunos ficaram surpresos como o extrato de solos pode responder ao indicador universal de repolho roxo, mudando a cor para rosa ou azul.

Durante a discussão, foi possível abordar que o $\mathrm{pH}$ do solo ácido não necessariamente compromete um ecossistema ou um cultivo agrícola. Há biomas como a Amazônia onde o solo é extremamente ácido e culturas agrícolas como a mandioca que cresce em solos ácidos. Apesar disso, o solo necessita ser básico para a maioria dos cultivos agrícolas poder germinar e crescer.

Nessa parte da discussão, os alunos também foram capazes de esquematizar todo o caminho que o alimento faz desde a plantação até a mesa do consumidor, fazendo uma análise crítica da importância do $\mathrm{pH}$ na produção de alimentos que são essenciais à nossa sobrevivência.

Quando foram perguntados sobre onde mais poderíamos perceber a importância do estudo de ácidos e bases no cotidiano, a grande maioria dos alunos falou sobre a chuva ácida. Um aluno argumentou que assim como a cal (óxido de cálcio) deixa o solo básico pelo contato com a água, há óxidos que viram ácidos em contato com a água. Foi possível também fazer uma reflexão sobre a quantidade de automóveis circulando todos os dias em Curitiba, onde muitos deles produzem tais óxidos que contribuem para a chuva ácida e também para outros problemas ambientais como o aquecimento global.

\section{CONSIDERAÇÕES FINAIS}

Este estudo teve como objetivo analisar como cada um dos três momentos pedagógicos contribui para o desenvolvimento do conhecimento científico e raciocínio crítico dos alunos. Sendo assim, foi elaborada uma oficina didática problematizadora como ferramenta didática. A análise da interação dos alunos durante a aplicação da Oficina, bem como das respostas destes em cada etapa da oficina nos permite inferir que a utilização da experimentação problematizadora foi satisfatória para o desenvolvimento da capacidade investigativa, para tornar o conteúdo curricular mais atraente ao aluno e para ampliar a visão da química na sociedade.

No estudo realizado, foi possível analisar os três momentos pedagógicos propostos por Delizoicov e avaliar sua influência em todo o processo. Além disso, foi possível realizar a experimentação em conjunto com a abordagem CTS a partir de produtos do cotidiano do aluno, o que tornou possível a realização do experimento em sala de aula.

Durante a aplicação do experimento, foi possível perceber também como o levantamento dos conhecimentos prévios dos alunos é imprescindível para determinar quais questões devem ser abordadas e quais decisões devem ser tomadas para o prosseguimento do experimento. Durante a realização de toda a oficina, foi possível notar o olhar de surpresa e curiosidade dos alunos quando estes confrontam seu conhecimento de senso comum com a compreensão científica relacionada ao experimento proposto.

A abordagem CTS proporcionou uma discussão mais crítica do experimento e suas aplicações, uma vez que possibilitou a relação entre os produtos agrícolas e 
abastecimento de alimentos à população, discussão já prevista pelo roteiro experimental. No entanto, mais do que isto, o debate também proporcionou um redirecionamento da discussão para temas mais abrangentes como chuva ácida e aquecimento global, aspectos relacionados ao terceiro momento pedagógico, o qual consiste em extrapolação do conhecimento. Também foi observado que, apesar de ser situações ambientais de escalas globais, ou seja, mais distantes do cotidiano, os alunos conseguiram refletir sobre o seu entorno, como por exemplo, a relação entre os automóveis (tecnologia) e o meio ambiente e sobre como restringir o uso do carro no dia a dia é uma ação que contribui para diminuir o lançamento de gases que contribuem para o efeito estufa.

Na etapa de realização do experimento em si, quando os alunos lidaram com as amostras, foi notável a grande participação dos mesmos e o interesse que demonstraram em realizar todas as etapas de maneira criteriosa. Como foi levantado nas pesquisas, nenhum deles havia realizado algum experimento anteriormente em sala de aula e são poucos os que já haviam tido contato visual com alguma atividade experimental.

Por fim, além de promover uma atividade experimental problematizadora dentro da abordagem de CTS, a Oficina também promoveu um primeiro contato daqueles alunos com uma atividade experimental, estimulando nestes o gosto pelo estudo das Ciências Naturais, em especial a Química. 


\title{
"HOW DOES PH AFFECTS SOIL QUALITY?": THE USE OF A PROBLEMATIZING EXPERIMENTAL DIDACTIC TO ANALYZE THE THREE PEDAGOGICAL MOMENTS
}

\begin{abstract}
Chemistry is considered a complex and uninteresting subject for most of the high school students. We consider that a way to transform the Chemistry into something interesting and understandable to students consists of using the problematizing experimentation combined to the Science, Technology and Society approach (STS), since these approaches can make teaching chemistry more contextualized and develop a criticism in students. This study aimed to elaborate and apply a problematizing experimental workshop, as well as to analyze the three pedagogical moments and their influence on the cognitive and critical development of the student from the question "How does pH affects soil quality?". A workshop was held within the content of acids, bases, $\mathrm{pH}$ and $\mathrm{pH}$ indicators and was attended by students from a pre-college preparation. From the analysis of the discussions carried out before and after each stage, it was notice that workshop contributed to the development of scientific knowledge and at the same time it allowed a critical reflection of reality. It is also noteworthy that the workshop promoted the first contact of students from a pre-college preparation with an experimental activity, perhaps constituting this fact, its main merit.
\end{abstract}

KEYWORDS: Problematizing experimentation. Purple cabbage indicator. STS. 


\section{REFERÊNCIAS}

CARDOSO, S. P.; COLINVAUX, D. Explorando a motivação para estudar química. Química Nova, v. 23, n. 3, p. 401-404, 2000.

CHASSOT, A. Alfabetização Cientifica: QUESTOES E DESAFIOS PARA A EDUCAÇAO. 5ạ Edição. UNIJUI, 2010.

DELIZOICOV, D. Ensino de física e a concepção freiriana de educação. Revista de Ensino de Física, v. 5, n. 2, p. 85-98, 1983.

Problemas e problematizações. Ensino de Física: conteúdo, metodologia e epistemologia numa concepção integradora. Florianópolis: ED. da UFSC, p. 125-150, 2001.

DOS SANTOS, W. L. P.; SCHNETZLER, R. P. Educação em Química: Compromisso com a Cidadania. 3a Edição, 2003.

DOS SANTOS, W. L. P. Contextualização no ensino de ciências por meio de temas CTS em uma perspectiva crítica. Ciência \& Ensino, v. 1, 2008.

FRANCISCO JR, W. E.; FERREIRA, L. H.; HARTWIG, D. R. Experimentação problematizadora: fundamentos teóricos e práticos para a aplicação em salas de aula de ciências. Química Nova na Escola, v. 30, n. 4, p. 34-41, 2008.

FREIRE, P. Pedagogia da autonomia: Saberes necessários à prática educativa. Editora Paz e Terra, 2011.

Pedagogia do oprimido. Editora Paz e Terra, 2013.

GIORDAN, M. O papel da experimentação no ensino de ciências. Química nova na escola, v. 10, n. 10, p. 43-49, 1999.

PEDUZZI, S. S. Concepções alternativas em Mecânica. Ensino de Física: conteúdo, metodologia e epistemologia numa concepção integradora, v. 2, p. 53-75, 2001.

WARTHA, E. J.; SILVA, E. D.; BEJARANO, N. R. R. Cotidiano e contextualização no ensino de Química. Química nova na escola, v. 35, n. 2, p. 84-91, 2013. 


\section{COMO O pH AFETA A QUALIDADE DO SOLO?}

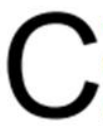

ertamente você já ouviu falar de substâncias ácidas e substâncias básicas. Ao falar delas, automaticamente já temos uma ideia de compostos perigosos e corrosivos. No entanto, ácidos e bases estão mais presentes no cotidiano e de uma forma menos agressiva do que se pensa. Desde alimentos e temperos (como o morango, o limão, a laranja e o vinagre) até produtos de limpeza e cosméticos (sabão em pó, detergente, sabonetes e xampus). Além disso, estão muito presentes no corpo humano, como o ácido clorídrico do estômago e o DNA e RNA das células. A principal maneira de identificar ácidos e bases é a partir de seus indicadores de $\mathrm{pH}$.

Mas por quê identificar substâncias ácidas e básicas? Onde podemos perceber a utilização de $\mathrm{pH}$ no cotidiano? Para o consumo de alimentos, tal medida é importante? É importante saber o $\mathrm{pH}$ para utilizar produtos do cotidiano?

Um indicador de $\mathrm{pH}$ fácil de ser confeccionado é a partir do extrato do repolho roxo. As substâncias presentes nas folhas de repolho roxo causam a mudança de cor em ácidos e bases e são chamadas de antocianinas. $\mathrm{O}$ indicador pode ser encontrado na seiva de muitas plantas, como uvas, amoras e beterrabas, mas também em folhas e flores coloridas, como a quaresmeira e a azaleia. As antocianinas são responsáveis pela coloração rosa laranja, vermelha, violeta e azul da maioria das flores.

Através do experimento a seguir, será construida uma escala de $\mathrm{pH}$ com base no indicador de repolho roxo. Converse com o professor que Ihe dará mais detalhes e os parâmetros para a realização da prática.

PARTE I: CONSTRUÇÃO DA ESCALA UNIVERSAL DE pH

\section{MATERIAL UTILIZADO}

- 1 repolho roxo

- 1 peneira

- 11 copos plásticos

- 1 colher de plástico

- Produtos utilizados no cotidiano: Limão; Vinagre; Refrigerante; Detergente; Sabonete Liquido; Água (destilada e da torneira); Bicarbonato de Sódio: Amoníaco; Sabão em pó; Soda cáustica.

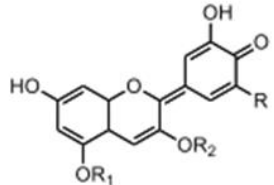

Figura 1. Fórmula Estrutural da Antocianin

\section{PROCEDIMENTO}

- Preparação do indicador

O repolho roxo deve ser fervido até liberar um líquido roxo e depois esfriado e peneirado. A solução deve ser armazenada resfriada para evitar que haja decomposição. O professor pode preparar a solução previamente.

- Análise das amostras

Para a coleta de dados, deverá ser construida uma tabela com a características das amostras conforme a Tabela 01 - Coleta de Dados das Amostras Cotidianas.

- Adição do indicador

$O$ indicador de repolho roxo deve ser adicionado a todas as amostras de maneira a se observar a mudança ou permanência da cor roxa. Os resultados devem ser descritos na tabela construida.

\section{- Análise de Resultados}

Após a observação de todas as amostras as quais o indicador fo adicionado, o Questionário 01 Organização das Informaçōes deverá ser respondido. 
$\mathrm{N}$ a primeira parte do experimento, construimos um indicador universal de $\mathrm{pH}$ por meio do caldo de fervura do repolho roxo. Mas para quê utilizar um indicador de $\mathrm{pH}$ ? $\mathrm{E}$ por que especificamente o indicador de repolho roxo é tăo interessante? É possivel utilizá-lo em situações mais práticas? Como uma análise de $\mathrm{pH}$ poderia interferir em alguma atividade do cotidiano?

Por meio da segunda parte do experimento, esperamos fornecer dados suficientes para que estas questōes e muitas outras sejam formuladas e discutidas.

PARTE II: UTILIZAÇÃO DO INDICADOR DE pH DO REPOLHO ROXO NA ANÁLISE DE SOLOS

\section{MATERIAL UTILIZADO}

- Amostra de solo com elevada carga orgânica

- Amostra de solo tratado com calcário

- Amostra de solo das redondezas do local do experimento

- 03 copos plásticos de $300 \mathrm{~mL}$

- 03 colheres de plástico

- Indicador de pH universal de repolho roxo

- 06 filtros de papel

- 01 funil

\section{PROCEDIMENTO}

\section{- Preparo das amostras de solo}

As amostras de solo deverão ser fervidas por 10 minutos com aproximadamente $200 \mathrm{~mL}$ de água.
Após a fervura, as amostras deverão ser deixadas esfriando em temperatura ambiente e depois filtradas nos copos plásticos com um funil utilizando filtro duplo para evitar rasgos. A solução filtrada é que será utilizada para a determinação de $\mathrm{pH}$ dos solos.

Essa parte do experimento pode ser realizada pelo professor previamente, uma vez que necessita do uso de fogo. No entanto, deve-se explicitar ao aluno o local de onde cada solo foi retirado.

\section{- Análise das amostras}

Para a coleta de dados, deverá ser construida uma tabela com a informações das amostras conforme a Tabela 02 - Coleta de

\section{Dados das Amostras de Solo}

\section{- Teste com o indicador de pH}

Em seguida, para determinar o $\mathrm{pH}$ de cada solo, deve-se adicionar o indicador de $\mathrm{pH}$ de repolho roxo aos copos plásticos contendo as amostras até observar ou não a mudança de coloração da solução. Os resultados observados devem ser registrados na tabela construida.

\section{- Análise de Resultados}

Após a observaçăo de todas as amostras de solo nas quais o indicador foi adicionado, haverá uma discussão de resultados com as perguntas norteadoras conforme a Discussão de Resultados da Análise dos Solos. Após a discussão, o professor pode solicitar uma atividade escrita ou um relatório como forma de avaliação. 
ANEXO 02. PRIMEIRA PARTE DO EXPERIMENTO: CONSTRUÇÃO DA ESCALA DE pH

Tabela 01 - Coleta de Dados das Amostras Cotidianas

\begin{tabular}{|l|l|l|}
\hline Nome da amostra & Principais observações & Mudanças ocorridas \\
\hline Limão & & \\
\hline Vinagre & & \\
\hline Refrigerante & & \\
\hline Detergente & & \\
\hline Água destilada & & \\
\hline Água da torneira & & \\
\hline Bicarbonato de sódio & & \\
\hline Bicarbonato de amônio & & \\
\hline Sabão em pó & & \\
\hline Soda cáustica & & \\
\hline Água sanitária & & \\
\hline
\end{tabular}

Questionário 01 - Organização das Informações:

1. Agrupe as amostras conforme a cor da solução final. Você consegue identificar substâncias ácidas, básicas ou neutras de acordo com a cor? Levando em conta o indicador de repolho roxo, qual cor corresponde a cada uma delas?

2. Quais outras substâncias do seu dia-a-dia podem ser adicionadas ao grupo dos ácidos? E quais podem ser adicionadas ao grupo das bases?

3. Qual a cor final dos copos contendo água? Qual pH está associado a estas cores? Você esperava que a água da torneira demonstrasse essa cor? Por quê?

4. O que é um indicador de $\mathrm{pH}$ universal? Que indicadores de $\mathrm{pH}$ universal você conhece?

5. O refrigerante possui caráter ácido ou básico?

6. Construa uma escala de $\mathrm{pH}$ com base nos resultados obtidos e no esquema dado.

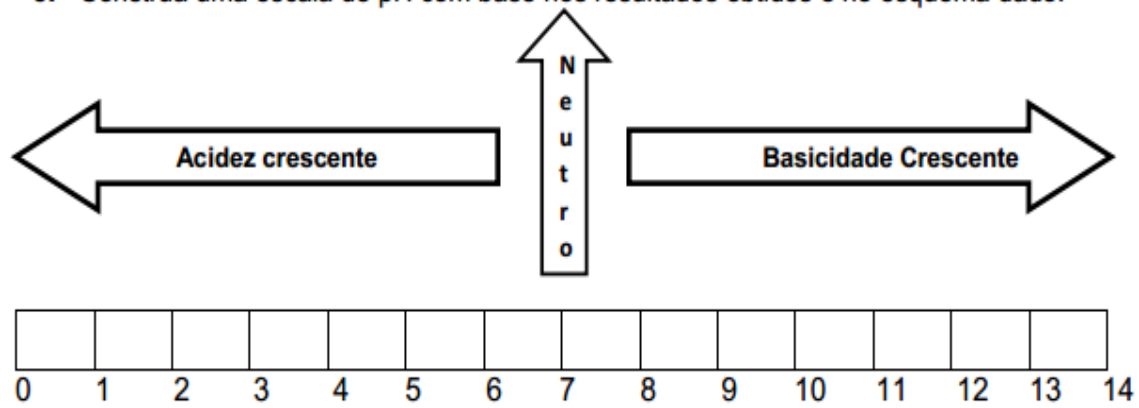


ANEXO 3. SEGUNDA PARTE DO EXPERIMENTO: ANÁLISE DE PH DOS SOLOS

Tabela 02 - Coleta de Dados das Amostras de Solo

\begin{tabular}{|c|c|c|c|}
\hline Amostra & Local de coleta & $\begin{array}{c}\text { Coloração } \\
\text { Observada }\end{array}$ & $\begin{array}{c}\text { Característica } \\
\text { Ácido-base }\end{array}$ \\
\hline $\begin{array}{c}\text { Solo com elevada } \\
\text { carga orgânica }\end{array}$ & & & \\
\hline $\begin{array}{c}\text { Solo tratado com } \\
\text { calcário }\end{array}$ & & & \\
\hline $\begin{array}{c}\text { Solo nas redondezas } \\
\text { do local do } \\
\text { experimento }\end{array}$ & & & \\
\hline
\end{tabular}

\section{Discussão de Resultados da Análise dos Solos:}

1. Tendo em vista que o Brasil é um país tropical cujo bioma terrestre predominante é a Amazônia, você consegue explicar o fato da maioria dos solos brasileiros serem de caráter ácido?

2. O que é calagem? Por que é necessário realizar a correção do pH do solo em cultivos agrícolas? A correção realizada é para aumentar ou diminuir o pH do solo?

3. Você consegue imaginar de que forma $\circ \mathrm{pH}$ do solo da indústria agrícola afeta $\circ$ consumo de alimentos? Quais as consequências o pH ácido do solo acarreta para a agroindústria? 


\section{ANEXO 4. CRITÉRIOS DEFINIDOS PELOS AUTORES PARA A CATEGORIZAÇÃO DAS RESPOSTAS}

As respostas obtidas em cada momento da oficina foram categorizadas como: Respostas Satisfatórias (RS), Respostas Pouco Satisfatórias (RPS) e Respostas Insatisfatórias (RI) em relação ao conhecimento científico, conforme os critérios abaixo:

Quadro 4-Critérios para os questionários do Primeiro Momento Pedagógico

Pergunta

Categorização
1. O que são substâncias ácidas e básicas?

2. Quais produtos do cotidiano são ácidos?

Cite pelo menos 3 .

3. Quais produtos do cotidiano são básicos?

Cite pelo menos 3 .

4. É possível identificar se uma substância é ácida ou básica? Como?
RS: Respostas que descrevam conceitualmente as substâncias (seja por teorias ácido-base ou pH); RPS: Respostas que tentam explicar o conceito, mas que possuem algum desvio do conhecimento científico; RI: Respostas totalmente desconectadas do conhecimento científico; RS: Citam corretamente 3 produtos de caráter ácido; RPS: Citam 2 produtos de caráter ácido; RI: Citam 1 ou nenhum produto de caráter ácido;

RS: Citam corretamente 3 produtos de caráter básico; RPS: Citam 2 produtos de caráter básico; RI: Citam 1 ou nenhum produto de caráter básico;

RS: Resposta afirmativa que apresenta uma maneira possível de determinar o caráter ácido-base; RPS: Respostas afirmativas genéricas que não propõe um método de análise; RI: Respostas negativas sem explicação ou propostas.

Fonte: Autores (2018).

Quadro 5 - Critérios para o questionário posterior ao Segundo Momento Pedagógico

Categorização

1. Agrupe as amostras conforme a cor da solução final. Você consegue identificar substâncias ácidas, básicas ou neutras de acordo com a cor? Levando em conta o indicador de repolho roxo, qual cor corresponde a cada uma delas?

2. Quais outras substâncias do seu dia-a-dia podem ser adicionadas ao grupo dos ácidos? E quais podem ser adicionados ao grupo das bases?

3. Qual a cor final dos copos contendo água? Qual $\mathrm{pH}$ associado a estas cores? Você esperava que a água da torneira demonstrasse essa

$$
\text { cor? Por quê? }
$$

RS: Respostas que apresentassem todas as associações de cores com suas respectivas características ácido-base; RPS: Respostas que associam incorretamente uma cor à sua respectiva característica ácido-base; RI: Respostas que apresentam duas ou mais associações de cores incorretas com as características ácido-base.

RS: Citam todos os produtos cotidianos corretos e diferentes das amostras para cada grupo; RPS: Citam 1 produto incorretamente para cada grupo; RI: Citam 2 ou mais produtos incorretamente para cada grupo.

RS: Respostas que formulem uma opinião e expliquem corretamente a hipótese; RPS: Respostas que formulem uma opinião e demonstrem uma tentativa de explicar a hipótese; RI: Respostas que não demonstrem qualquer tentativa de explicar a coloração. 
4. $\mathrm{O}$ que é um indicador de $\mathrm{pH}$ universal? Que indicadores de $\mathrm{pH}$ universal você conhece?
RS: Respostas que citem corretamente a explicação do termo "universal", podendo citar ou não um exemplo; RPS: Respostas que tentem explicar a razão do termo "universal", mas que apresentem desvios do conhecimento científico;

RI: Respostas que não apresentem qualquer tentativa de explicar o termo.

Fonte: Autores (2018).

Tabela 6 - Critérios para questionário prévio ao Terceiro Momento Pedagógico

Pergunta

Categorização

RS: Respostas afirmativas que consigam exemplificar a importância da análise de pH dos solos; RPS: Respostas

1. É importante determinar o $\mathrm{pH}$ dos solos? Por quê?

2. Você sabe o que é calagem? Para que serve? 0 $\mathrm{pH}$ do solo aumenta ou diminui depois da calagem?

3. $\mathrm{O} \mathrm{pH}$ dos solos interfere na produção de alimentos? Como? afirmativas, mas genéricas quanto à necessidade da análise de $\mathrm{pH}$; RI: Respostas negativas que não apresentem qualquer explicação ou tentativa de explicação para a análise de $\mathrm{pH}$;

RS: Respostas que descrevessem corretamente o processo de calagem, sua utilização e esclarecesse o aumento do $\mathrm{pH}$ do solo; RPS: Respostas que tentassem descrever o processo de calagem e seu propósito, mas que errassem ao dizer a diminuição do $\mathrm{pH}$, ou que

tentassem descrever a ação no $\mathrm{pH}$, mas não explicitassem o método completo. RI: Respostas que não esclarecessem o método e que também não relacionasse o $\mathrm{pH}$.

RS: Respostas que dessem um exemplo concreto ou cotidiano sobre a relação entre o cuidado com o solo e a produção de alimentos; RPS: Respostas afirmativas, mas sem explicação ou tentativa de explicação; RI: Respostas negativas ou sem a tentativa de explicar a resposta.

Fonte: Autores (2018). 
Recebido: 15 jan. 2018

Aprovado: 27 mai. 2020

DOI: $10.3895 /$ rbect.v13n2.7624

Como citar: TAKARADA, W. H.; AIRES, J. A. "Como o pH afeta a qualidade do solo?": a utilização de uma oficina experimental problematizadora para a análise dos três momentos pedagógicos. Revista Brasileira de Ensino de Ciência e Tecnologia, Ponta Grossa, v.13, n. 2, p. 217-246, mai./ago. 2020. Disponível em: $<$ https://periodicos.utfpr.edu.br/rbect/article/view/7624>. Acesso em: XXX.

Correspondência: Willian Hideki Takarada - hidetak10@gmail.com

Direito autoral: Este artigo está licenciado sob os termos da Licença Creative Commons-Atribuição 4.0 Internacional.

(c) (1) 